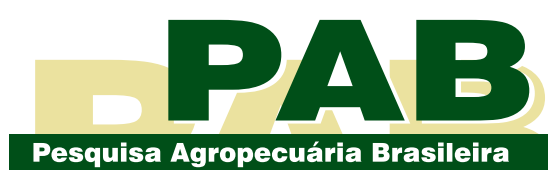

ISSN 1678-3921

Journal homepage: www.embrapa.br/pab

For manuscript submission and journal contents, access: www.scielo.br/pab

\section{Agricultural zoning of climate risk for Physalis peruviana cultivation in Southeastern Brazil}

\begin{abstract}
The objective of this work was to elaborate the agricultural zoning of climatic risk (ZARC) for Physalis peruviana, through the thermal and water requirements of the crop in Southeastern Brazil. Air temperature $\left(\mathrm{T}_{\mathrm{AIR}}\right)$ and precipitation $\left(\mathrm{P}_{\mathrm{YEAR}}\right)$ data from 1,530 meteorological stations covering the entire region were used. Regions were considered climatically favorable to Physalis peruviana when $\mathrm{T}_{\mathrm{AIR}}$ was between 13 and $18^{\circ} \mathrm{C}$ and $P_{\text {YEAR }}$ between 1,000 and 2,000 mm per year. Regions where $T_{\text {AIR }}$ was above $30^{\circ} \mathrm{C}$ or less than $13^{\circ} \mathrm{C}$ were considered inapt. Maps were created with this information and used to identify climatic characteristics and to establish the agricultural aptitude classes, termed apt, inapt, and marginal for the cultivation of Physalis peruviana. The Southeastern region of Brazil showed a thermal variation from 16.5 to $22.6^{\circ} \mathrm{C}$ and water amplitude from 800 to $2,800 \mathrm{~mm}$. ZARC shows that $10 \%$ of Southeastern Brazil is climatically apt for the cultivation of Physalis peruviana, corresponding to the following regions of Brazilian states: central and southern Minas Gerais, western Rio de Janeiro and Espírito Santo, and eastern and southern São Paulo.
\end{abstract}

Index terms: climate risk, agrometeorology, modeling, big data.

\section{Zoneamento agrícola de risco climático para o cultivo de Physalis peruviana no Sudeste do Brasil}

Resumo - O objetivo deste trabalho foi elaborar o zoneamento agrícola de risco climático (ZARC) para Physalis peruviana, por meio das exigências térmicas e hídricas da cultura na região Sudeste do Brasil. Foram utilizados dados de temperatura do ar $\left(\mathrm{T}_{\mathrm{AR}}\right)$ e precipitação $\left(\mathrm{P}_{\mathrm{ANO}}\right)$ de 1.530 estações meteorológicas que contemplam toda a região. As regiões foram consideradas climaticamente favoráveis a Physalis peruviana quando a $\mathrm{T}_{\mathrm{AR}}$ foi entre 13 e $18^{\circ} \mathrm{C}$ e a $\mathrm{P}_{\mathrm{ANO}}$ entre 1.000 e $2.000 \mathrm{~mm}$ por ano. As regiões com $\mathrm{T}_{\mathrm{AR}}$ acima de $30^{\circ} \mathrm{C}$ ou abaixo de $13^{\circ} \mathrm{C}$ foram consideradas inaptas. Os mapas foram construídos a partir dessas informações e usadas para identificar as características climáticas e estabelecer as classes de aptidão agrícola, denominadas aptas, inaptas e marginais para o cultivo de Physalis peruviana. A região Sudeste apresentou variação térmica de 16,5 a $22,6^{\circ} \mathrm{C}$ e amplitude hídrica de 800 a $2.800 \mathrm{~mm}$. O ZARC mostra que $10 \%$ da região Sudeste do Brasil são climaticamente aptos ao cultivo do Physalis peruviana, o que corresponde às regiões: Central e Sul de Minas Gerais, Oeste do Rio de Janeiro e do Espírito Santo e Leste e Sul de São Paulo.

Termos para indexação: risco climático, agrometeorologia, modelagem, big data. 


\section{Introduction}

Physalis (Physalis peruviana) is a non-native species that has been increasingly cultivated in Brazil (Palomino et al., 2011). Native to the Andes mountains of Peru, South America (Fischer \& Almanza-Merchán, 1993), it belongs to the family Solanaceae, and can grow up to $2 \mathrm{~m}$ height (Ligarreto et al., 2005). Fruit production per plant at harvest is estimated to be between 2 and $3 \mathrm{~kg}$, and the productive period until harvest can last 8 months, during which the branches, flowers, and fruit are simultaneously produced (Lima et al., 2012).

The ideal temperature for physalis cultivation ranges between 13 and $18^{\circ} \mathrm{C}$, and this species is productive up to $30^{\circ} \mathrm{C}$ (Salazar et al., 2008a; Fischer et al., 2014); however, above this temperature, flowering and, consequently, fruit production, are subject to severe reductions. The ideal hydrologic regime for cultivation of physalis is between 1,000 to $2,000 \mathrm{~mm}$, with equal distribution throughout the year, and air relative humidity to prevent fruit deterioration should be between 70 and $80 \%$ (Fischer, 2000; Rufato et al., 2008). Precipitation values above this range stimulate excess vegetative growth, and increase the incidence of diseases.

Climatic risk zoning (ZARC) is obtained using the predominant meteorological information of a region together with the bioclimatic characteristics of the cultivated crop species. Wollmann \& Galvani (2013) described a ZARC as the delimitation of regions that are considered apt for the development of an agricultural crop, taking into consideration macroscale and regional climate conditions, as well as the thermal and hydrological demands of the species. Studies have been conducted on climate zoning for physic nut (Jatropha curcas L.) in the state of Goiás (Pena et al., 2016), banana in Rio Doce valley in the state of Minas Gerais (Coelho et al., 2016), and for açaí in the state of Espírito Santo (Gasparini et al., 2015). A ZARC can have a wide applicability for a large part of agricultural crops in a specific region, but to date no studies have been done for physalis.

A ZARC is important for identifying regions that are apt, inapt, or marginal, and can aid to reduce risks involved with agricultural activities (Aparecido et al., 2018), thus increasing the level of confidence of producers that cultivate the plant species analyzed by ZARC. Physalis is a species that is relatively new to the
Southeastern Brazil, and has been steadily increasing in planted areas. A large portion of the harvest is consumed in Brazil and is also exported to Colombia (Salazar et al., 2008a; López Enríquez et al., 2016), but there is a lack of studies that analyze whether or not the predominant climatic conditions of Southeastern Brazil are apt for the development of physalis.

The objective of this work was to elaborate a ZARC based on the thermal and hydrological characteristics of physalis for the Southeast of Brazil.

\section{Materials and Methods}

The data for average air temperature $\left(\mathrm{T}_{\mathrm{AIR}}\right)$ and monthly rainfall $\left(\mathrm{P}_{\mathrm{YEAR}}\right)$ representing the pattern for the period 1950 to 2015 were obtained from 1,530 meteorological stations spread across Southeastern Brazil (Figure 1). This region has an area of approximately $924,620 \mathrm{~km}^{2}$, in which the predominant Köppen and Geiger (1928) climate classes are: Af, Am, Aw, Cfa, Cfb, Cwa, and Cwb (Alvares et al., 2014).

The climatic variables $\mathrm{T}_{\mathrm{AIR}}$ and $\mathrm{P}_{\mathrm{YEAR}}$ were defined in accordance with the cultivation characteristics of physalis (Fischer, 2000; Salazar et al., 2008b). Using a combination of different climatic variables based on the scientific literature (Fischer, 2000; Rufato et al., 2008; Salazar et al., 2008a), the climate zoning classes were established for physalis (Figure 2).

The studied regions were considered climatically favorable for physalis when $\mathrm{T}_{\mathrm{AIR}}$ was between 13 and $18^{\circ} \mathrm{C}$, and $P_{\text {YEAR }}$ was between 1,000 and $2,000 \mathrm{~mm}$ per year. Regions where $\mathrm{T}_{\mathrm{AIR}}$ was above $30^{\circ} \mathrm{C}$ or less than $13^{\circ} \mathrm{C}$ were considered inapt (Fischer, 2000; Rufato et al., 2008; Salazar et al., 2008a; Fischer et al., 2014).

Areas considered marginal had the following restrictions: $1^{\text {st }}, \mathrm{T}_{\mathrm{AIR}}$ between 18 and $30^{\circ} \mathrm{C}$, vigorous vegetation; $2^{\text {nd }}, \mathrm{T}_{\mathrm{AIR}}$ between 13 and $18^{\circ} \mathrm{C}$ and $\mathrm{P}_{\mathrm{YEAR}}$ $>2,000 \mathrm{~mm}$, excess presence of diseases; $3^{\text {rd }}, \mathrm{T}_{\mathrm{AIR}}$ between 13 and $18^{\circ} \mathrm{C}$ and $\mathrm{P}_{\mathrm{YEAR}}<2,000 \mathrm{~mm}$, water deficit (Fischer, 2000; Rufato et al., 2008; Salazar et al., 2008a). The interposition of these data was conducted using the tool "raster.calculator".

With the establishment of the apt, inapt, and marginal climate classes for the ZARC, the hydrological balance was calculated following Thornthwaite \& Mather (1955), to refine the characterization of each climate class.

In order to calculate the hydrological balance, the potential evapotranspiration (ETP) was calculated according to Thornthwaite (1948):

Pesq. agropec. bras., Brasília, v.54, e00057, 2019

DOI: 10.1590/S1678-3921.pab2019.v54.00057 


$$
\begin{aligned}
& \mathrm{ETP}=\mathrm{ETp} \times \mathrm{COR} \text {; } \\
& \begin{cases}\mathrm{ETp}=16 \times\left(10 \times \frac{\text { Tair }}{\mathrm{I}}\right)^{\mathrm{a}} ; & \text { if } 0 \leq \text { Tair }<26.5^{\circ} \mathrm{C} \\
\mathrm{ETp}=-415.85+32.24 \times \text { Tair }-0.43 \mathrm{Tair}^{2} ; & \text { if } \text { Tair } \geq 26.5^{\circ} \mathrm{C}\end{cases} \\
& \mathrm{I}=\sum_{\mathrm{n}=1}^{12}(0.2 \times \text { Tair })^{1.514} \text {; } \\
& \mathrm{a}=0.49239+1.7912 \times 10^{-2} \times \mathrm{I}-7.71 \times 10^{-5} \times \mathrm{I}^{2}+6.75 \times 10^{-7} \times \mathrm{I}^{3} \text {; } \\
& \mathrm{COR}=\frac{\mathrm{N}}{12} \times \frac{\mathrm{NDP}}{30} \text {; }
\end{aligned}
$$

in which: ETP is the potential evapotranspiration $(\mathrm{mm}$ per month); ETp is the reference evapotranspiration; COR is a correction factor in function of the real number of days, and of the monthly photoperiod; $\mathrm{T}_{\mathrm{AIR}}$ is the average monthly temperature; $\underline{I}$ is an index that expresses the level of heat of the region; $\mathrm{a}$ is the regional thermal index; NDP is the number of days of the period, and $\mathrm{N}$ is the average photoperiod for the month.

After the calculation of ETP, the components of the hydrological balance (water deficiency - DEF, and excess - SUR) were calculated for all sites:

$$
\begin{aligned}
& \text { if }(\mathrm{P}-\mathrm{ETP})_{\mathrm{i}}<0=\left\{\begin{array}{l}
\mathrm{NAC}_{\mathrm{i}}=\mathrm{NAC}_{\mathrm{i}}-1+(\mathrm{P}+\mathrm{ETP})_{\mathrm{i}} \\
\mathrm{STO}_{\mathrm{i}}=\mathrm{WC}_{\mathrm{e}} \frac{\left(\mathrm{NAC}_{\mathrm{i}}\right)}{\mathrm{WC}}
\end{array} ;\right. \\
& \text { if }(\mathrm{P}-\mathrm{ETP})_{\mathrm{i}} \geq 0=\left\{\begin{array}{l}
\mathrm{STO}_{\mathrm{i}}=(\mathrm{P}+\mathrm{ETP})_{\mathrm{i}}+\mathrm{STO}_{\mathrm{i}-1} \\
\mathrm{NAC}_{\mathrm{i}}=\mathrm{WC} \ln \frac{\left(\mathrm{STO}_{\mathrm{i}}\right)}{\mathrm{WC}}
\end{array} ;\right. \\
& \mathrm{ALT}_{\mathrm{i}}=\mathrm{STO}_{\mathrm{i}}-\mathrm{STO}_{\mathrm{i}-1} \text {; } \\
& \mathrm{AET}_{\mathrm{i}}=\left\{\begin{array}{l}
\mathrm{P}+\left|\mathrm{ALT}_{\mathrm{i}}\right|, \text { if } \mathrm{ALT}<0 \\
\mathrm{ETP}_{\mathrm{i}}, \text { if } \mathrm{ALT} \geq 0
\end{array}\right. \text {; } \\
& \mathrm{DEF}=\mathrm{PET}-\mathrm{AET} \text {; } \\
& \mathrm{SUR}_{\mathrm{i}}=\left\{\begin{array}{l}
0, \text { if } \mathrm{ALT}<0 \\
(\mathrm{P}-\mathrm{ETP})_{\mathrm{i}}-\mathrm{ALT}_{\mathrm{i}}, \text { if } \mathrm{WC}=0
\end{array} ;\right.
\end{aligned}
$$

in which: ETP is the potential evapotranspiration (mm per month); WC is the available water capacity $(\mathrm{mm})$; STO is the soil-water storage $(\mathrm{mm})$; NAC is the sum of rainfall - potential evapotranspiration $(\mathrm{mm})$; DEF is the deficit of water in the soil-plantatmosphere system (mm); SUR is the excess water in the soil-plant-atmosphere system (mm); ALT is the soil-water storage for the actual month - the soil-

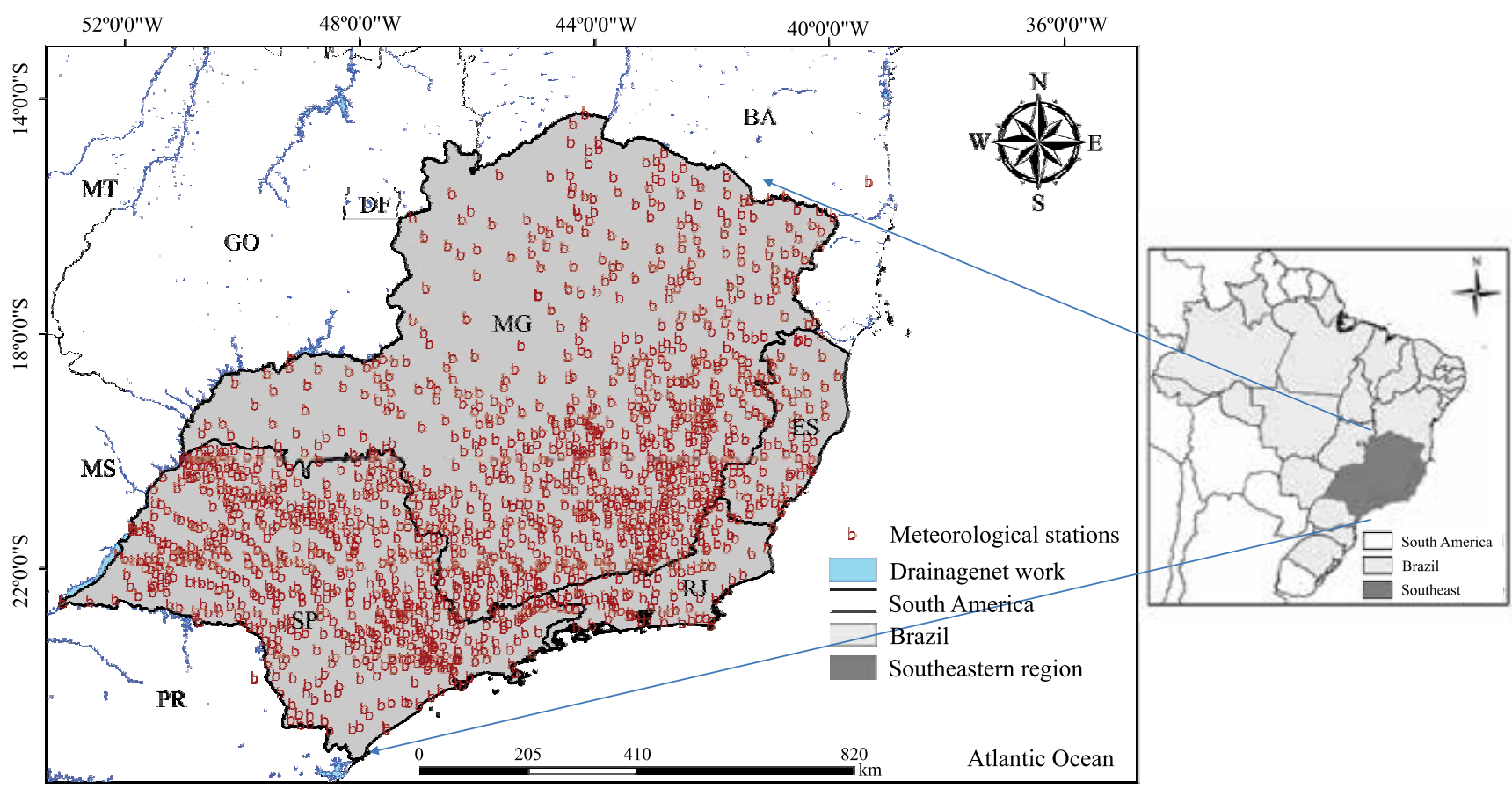

Figure 1. Agrometeorological stations used in the climatic risk agricultural zoning for physalis in the Southeastern Brazil. Source: Inmet (2015). 
water storage for the previous month $(\mathrm{mm})$; and $\mathrm{i}$ is the monthly period.

The calculated hydrological balance used the capacity of available water (CAD) between $60-100 \mathrm{~mm}$, which is a value that represents the effective rooting depth of physalis and is expressed by the following equation $\mathrm{CAD}=\left(\Theta_{\mathrm{CC}}-\Theta_{\mathrm{PMP}}\right) \times 1.2 \times 600$; in which: $\Theta_{\mathrm{CC}}$ is the humidity based on the mass at field capacity; $\Theta_{\mathrm{PMP}}$ is the humidity based on the mass at the wilting point.

Geographic information system (GIS) technology was used to analyze the spatial interpolation of the $\mathrm{T}_{\mathrm{AIR}}$ and $\mathrm{P}_{\mathrm{YEAR}}$ values for all sites spread across the Southeastern Brazil. This analysis was conducted using kriging (Krige, 1951) with neighboring data points with a resolution of $0.25^{\circ}(27.75 \mathrm{~km})$ in a spherical model.

The interposition of climate information $\left(\mathrm{T}_{\mathrm{AIR}}\right.$ and $\mathrm{P}_{\mathrm{YEAR}}$ ) was conducted using the tool "raster.calculator", along with the data interpolation for the construction of the ZARC of physalis for the Southeastern Brazil.

\section{Results and Discussion}

Southeastern Brazil has a thermal variation between 16.5 and $22.6^{\circ} \mathrm{C}$ and average thermal amplitude of $6^{\circ} \mathrm{C}$. The highest $\mathrm{T}_{\mathrm{AIR}}$ occurred in the area of Triangulo Mineiro that consists of parts of the northeast of the state of São Paulo, the north of the state of Minas Gerais, and the east of the state of Espírito Santo, with values above $22.6^{\circ} \mathrm{C}$. The lowest $\mathrm{T}_{\mathrm{AIR}}$ are concentrated in the south of the state of Minas Gerais, where values below $16.5^{\circ} \mathrm{C}$ were recorded (Figure $3 \mathrm{~A}$ ). This TAIR variation was also described by Alvares et al. (2014). The $\mathrm{P}_{\text {YEAR }}$ had a large variability across Southeastern Brazil (Figure $3 \mathrm{~B}$ ). The lowest values for $\mathrm{P}_{\mathrm{YEAR}}$ were $<800 \mathrm{~mm}$ per year (Figure $3 \mathrm{C}$ ) and occurred in the

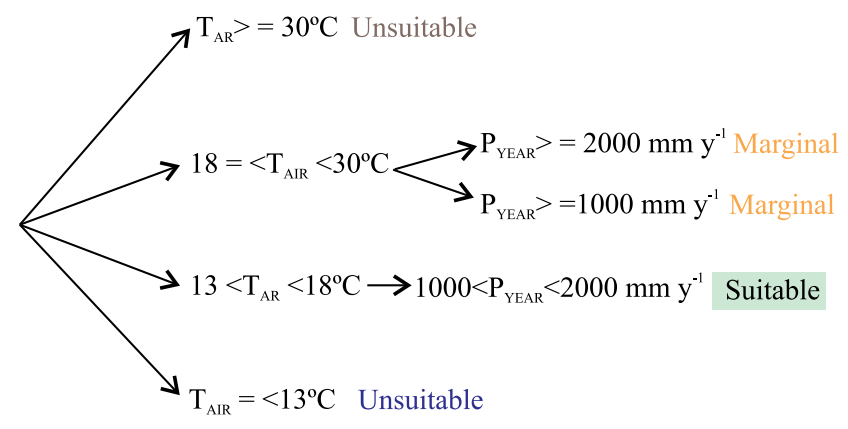

Figure 2. Classification criteria for adaptability of physalis based on agroclimatic attributes: $\mathrm{T}_{\mathrm{AR}}$, annual average air temperature $\left({ }^{\circ} \mathrm{C}\right)$, and $\mathrm{P}_{\mathrm{ANO}}$, annual rainfall $(\mathrm{mm})$.
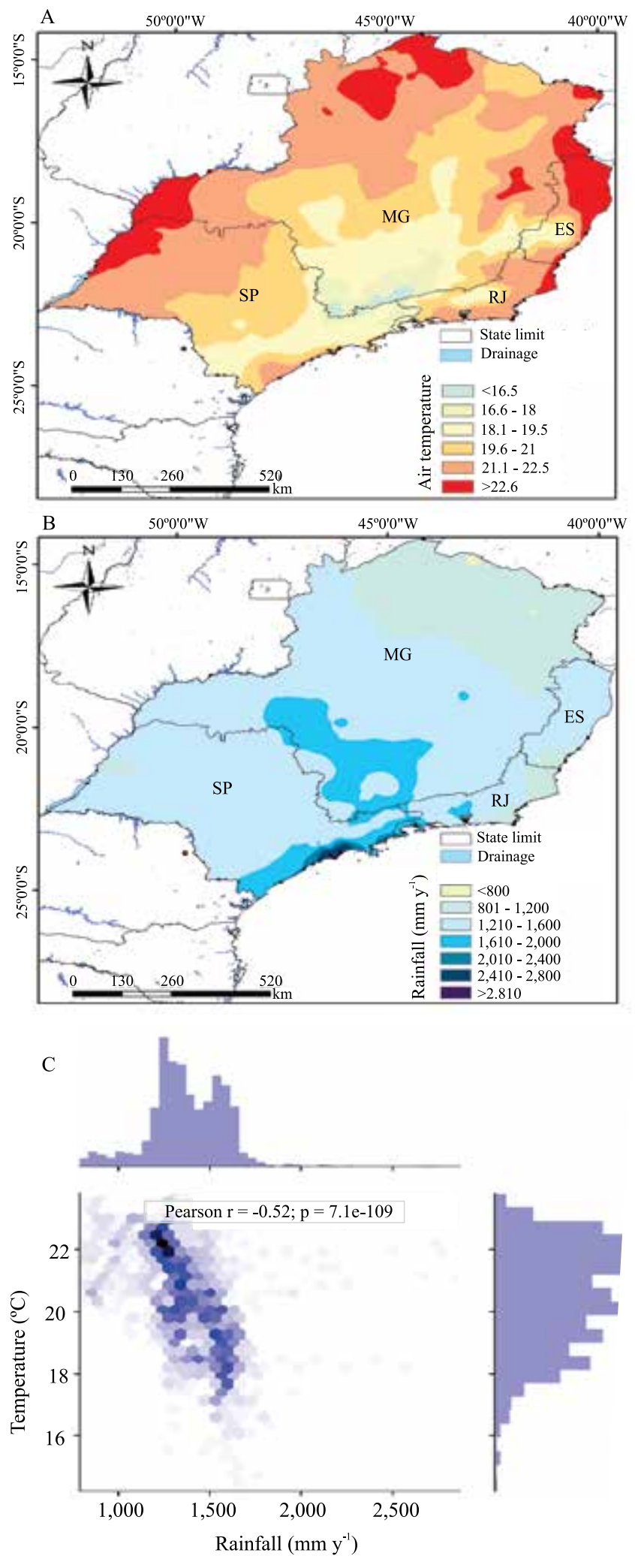

Figure 3. Map of the spatial variability of air temperature (A), rainfall (B), and distribution of temperature and precipitation (C), in the Southeastern Brazil. 
Jequitinhonha valley and in the northern of the state of Minas Gerais. The highest $\mathrm{P}_{\mathrm{YEAR}}$ were $<2,800 \mathrm{~mm}$ per year in the Paraíba valley (in the São Paulo state), as well as in a small area of the Sul Fluminense region, and in the Mantiqueira mountains in the area of Alto Paranaíba (in the Minas Gerais state). In the most Southeastern Brazil, the $\mathrm{P}_{\mathrm{YEAR}}$ varied between 1,200 and $1,600 \mathrm{~mm}$ year (Figure $3 \mathrm{~B}$ ). This $\mathrm{P}_{\mathrm{YEAR}}$ variation was also described by Aparecido et al. (2017).

The ZARC for Physalis peruviana shows that the south and metropolitan regions of Minas Gerais, the western of Rio de Janeiro and Espírito Santo states, and the eastern and southern of São Paulo state, are the areas with the most favorable climate conditions for the success of physalis plantations (Figure 4). The remainder of the analyzed regions was considered marginal, as these areas showed at least one restriction to physalis cultivation.

Out of the total area, $10 \%$ of the Southeastern Brazil was considered apt for physalis cultivation, and the areas with $\mathrm{T}_{\mathrm{AIR}}$ above the ideal ( $\mathrm{1}^{\text {st }}$ restriction) represent $80 \%$ of the Southeastern Brazil. In these areas physalis would be restricted due to the need of closing its stomata, consequently causing a reduction of gas exchange and evapotranspiration, and these effects would reduce plant productivity (Taiz \& Zeiger, 2017). To cultivate physalis in areas with high $T_{\text {AIR }}$, it would be necessary to adopt strategies to reduce climate adversity, such as the use of polyethylene shading screens, or mixtures of different crops such as shrubs or trees to reduce $\mathrm{T}_{\mathrm{AIR}}$. Areas with high indices of disease due to excess $\mathrm{P}_{\mathrm{YEAR}}$ represent $1 \%$ of the Southeast region of Brazil. In these areas, the solution is to use a system with an efficient drainage or protection, able to control the entry of water into the system, for the physalis plantation (semi-enclosed greenhouses). In regions with recurring water deficits due to low values of $\mathrm{P}_{\mathrm{YEAR}}(9 \%)$, irrigation systems are recommended, in order to satisfy the crop-water requirements.

Areas deemed apt for physalis cultivation have a $\mathrm{P}_{\mathrm{YEAR}}$ of $1,560 \mathrm{~mm}$ (Figure $5 \mathrm{~A}$ ), with a slight water

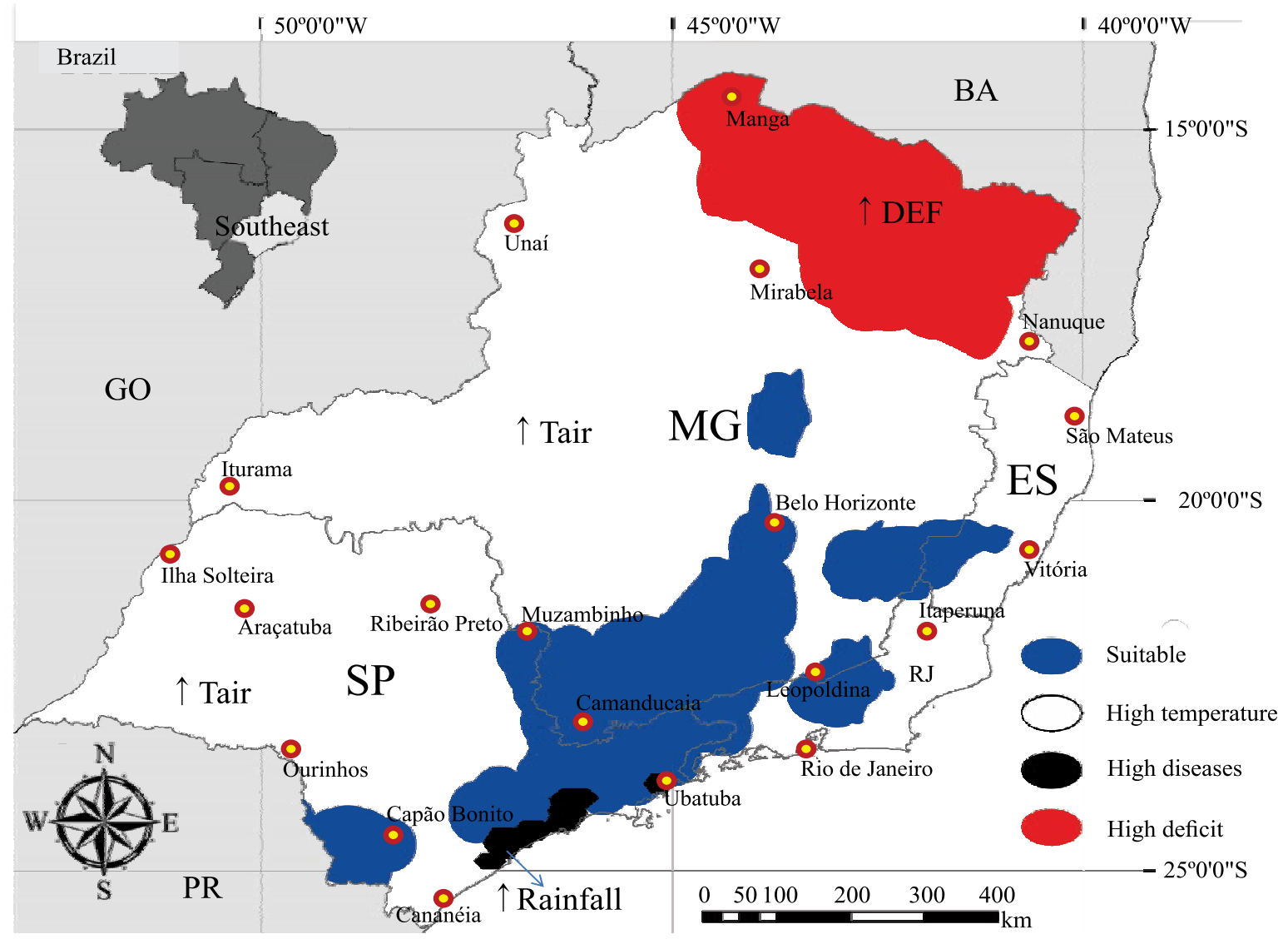

Figure 4. Agricultural climate risk zoning for physalis in the Southeastern Brazil. 

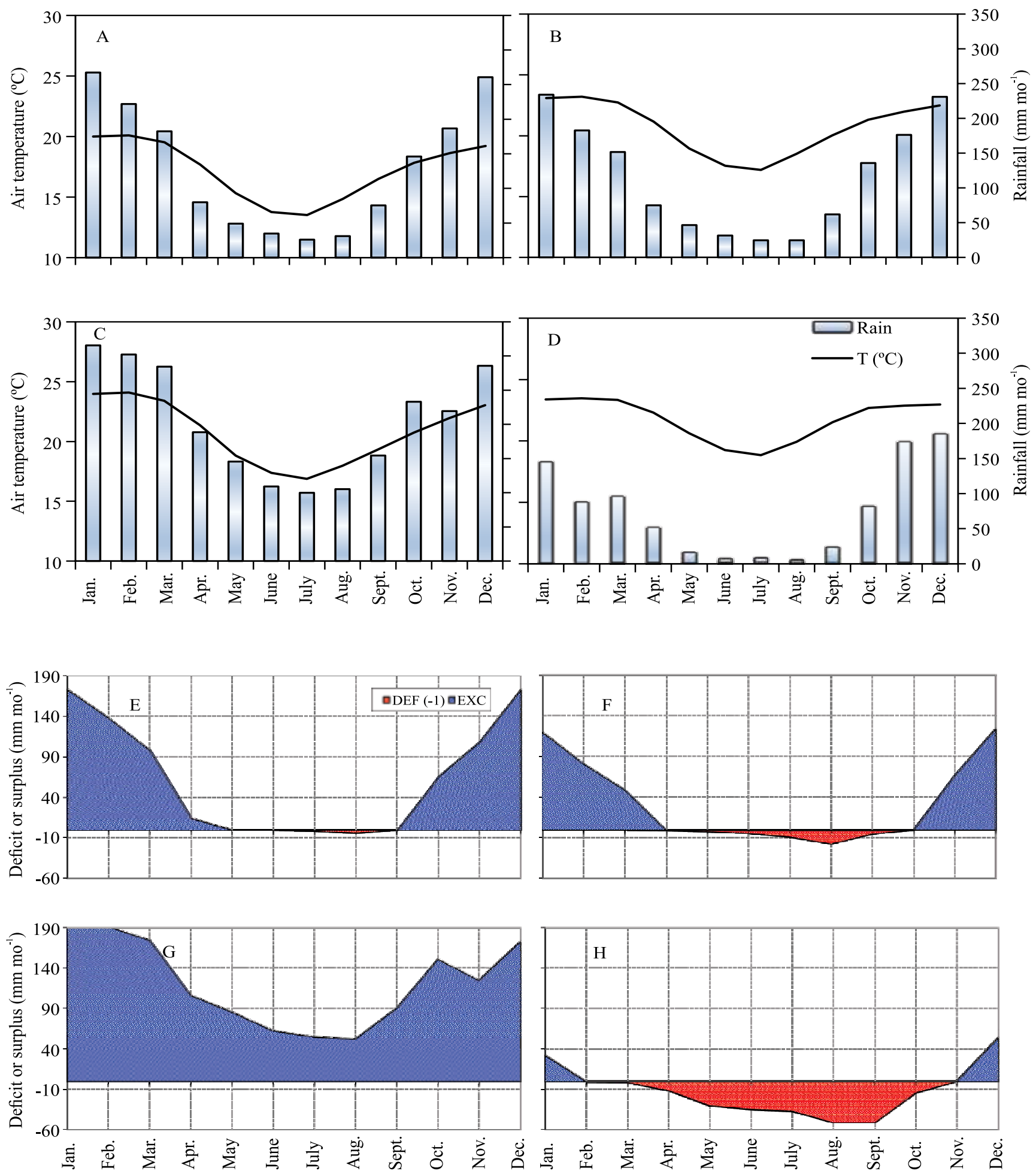

Figure 5. Seasonal variation of monthly air temperature and monthly rainfall for areas considered apt (A), and marginal (B $=$ first restriction, high temperatures; $\mathrm{C}=$ second restriction, excess diseases; $\mathrm{D}=$ third restriction, water deficit), and climate hydrological balance for areas considered apt $(E)$, and marginal ( $F=$ first restriction, high air temperatures; $G=$ second restriction, excess diseases; $\mathrm{H}=$ third restriction, water deficit), for the agricultural zoning of climate risk for physalis in Southeastern Brazil. 
deficit during the July and August (Figure 5 E). The regions with restrictions due to high $\mathrm{T}_{\mathrm{AIR}}$ show water deficit from April to September (Figure $5 \mathrm{~F}$ ), and $\mathrm{T}_{\mathrm{AIR}}$ average of $20^{\circ} \mathrm{C}$ (Figure $5 \mathrm{~B}$ ). Areas with high $\mathrm{P}_{\mathrm{YEAR}}$, as is the case for the coastal region of the state of São Paulo, have rainfall indices near $2,400 \mathrm{~mm}$ per year (Figure $5 \mathrm{C}$ ) and surplus above $1,300 \mathrm{~mm}$ per year (Figure $5 \mathrm{G}$ ).

The north of the state of Minas Gerais, and the Jequitinhonha valley and Mucuri were regions that characterized as being marginal because they have $\mathrm{P}_{\text {YEAR }}$ of $900 \mathrm{~mm}$ per year (Figure $5 \mathrm{D}$ ) and a large water deficit from February to October (Figure $5 \mathrm{H}$ ). Water stress due to deficit is one of the meteorological variables with the largest negative correlation with productivity of agricultural crops (Martins et al., 2015). Not only the presence of high-water deficits causes stomatal closing, but they cause also a reduction of evapotranspiration (Aparecido et al., 2017), which has - as a direct consequence - a reduction of net photosynthesis (Larcher, 2006). Sinclair \& Ludlow (1986) highlight that besides reducing transpiration, water stress can also affect the growth and development of agricultural crops.

\section{Conclusions}

1. Climatic risk zoning for Physalis peruviana show that $10 \%$ of the Southeastern Brazil is apt for cultivation of this plant; the areas considered most apt are the center/southern parts of the state of Minas Gerais; the western portions of the states of Rio de Janeiro and Espírito Santo, and the southern and eastern of the state of São Paulo.

2. The largest restriction to the development of Physalis peruviana is the high-air temperature, a condition which is present in $80 \%$ of the studied area.

\section{References}

ALVARES, C.A.; STAPE, J.L.; SENTELHAS, P.C.; MORAESGONÇALVES, J.L. de; SPAROVEK, G. Köppen's climate classification map for Brazil. Meteorologische Zeitschrift, v.22, p.711-728, 2014. DOI: https://doi.org/10.1127/09412948/2013/0507.

APARECIDO, L.E. de O.; ROLIM, G. de S.; MORAES, J.R. da S.C. de; ROCHA, H.G.; LENSE, G.H.E.; SOUZA, P.S. Agroclimatic zoning for urucum crops in the state of Minas Gerais, Brazil. Bragantia, v.77, p.193-200, 2018. DOI: https://doi.org/10.1590/1678-4499.2016527.
APARECIDO, L.E. de O.; ROLIM, G. de S.; LAMPARELLI, R.A.C.; SOUZA, P.S. de; SANTOS, E.R. dos. Agrometeorological models for forecasting coffee yield. Agronomy Journal, v.109, p.249-258, 2017. DOI: https://doi.org/10.2134/agronj2016.03.0166.

COELHO, G.O.; DIAS, L.A. dos S.; FINGER, F.L. Agro-climatic zoning to banana-growing in the mesoregion of Vale do Rio Doce. Revista Brasileira de Fruticultura, v.38, e-908, p.1-14, 2016. 14p. DOI: https://doi.org/10.1590/0100-29452016908.

FISCHER, G. Crescimiento y desarrollo. In: FLÓREZ, V.J.; FISCHER, G.; SORA R., Á, D. Producción, poscosecha y exportación de la uchuva (Physalis peruviana L.). Santa Fe de Bogota: Universidade Nacional de Colombia, 2000. p.9-26.

FISCHER, G.; ALMANZA-MERCHÁN, P.J.; MIRANDA, D. Importancia y cultivo de la uchuva (Physalis peruviana L.). Revista Brasileira de Fruticultura, v.36, p.1-15, 2014. DOI: https://doi.org/10.1590/0100-2945-441/13.

FISCHER, G.; ALMANZA-MERCHÁN, P.J. La uchuva (Physalis peruviana L.) una alternativa promisoria para las zonas altas de Colombia. Agricultura Tropical, v.30, p.79-87, 1993.

GASPARINI, K.A.C.; FONSECA, M.D.S.; PASTRO, M.S.; LACERDA, L.C.; SANTOS, A.R. dos. Zoneamento agroclimático da cultura do açaí (Euterpe oleracea Mart.) para o estado do Espírito Santo. Revista Ciência Agronômica, v.46, p.707-717, 2015. DOI: https://doi.org/10.5935/1806-6690.20150057.

INMET. Instituto Nacional de Meteorologia. Normais climatológicas do Brasil: 1961-1990. Brasília, 2015. Available at: $\quad<$ http://www.inmet.gov.br/portal/index.php?r=clima/ normaisclimatologicas $>$. Accessed on: Mar. 10, 2017.

KÖPPEN, W.; GEIGER, R. Klimate der Erde. Gotha: Verlag Justus Perthes, 1928.

KRIGE, D. G. A statistical approach to some mine valuations and allied problems at the Witwatersrand. 1951. 272p. Thesis (Master's) - University of Witwatersrand, Johannesburg.

LARCHER, W. Ecofisiologia vegetal. São Carlos: RiMa, 2006. $531 \mathrm{p}$.

LIGARRETO, G.A.; LOBO, M.; CORREA, A. Recursos geneticos del genero Physalis en Colombia. In: FISCHER, G.; MIRANDA, D.; PIEDRAHÍTA, W.; ROMERO, J. (Ed.). Avances en cultivo, poscosecha y exportación de la uchuva (Physalis peruviana L.) en Colombia. Bogotá: Universidad Nacional de Colombia, 2005. p.9-26.

LIMA, C.S.M.; GALARÇA, S.P.; BETEMPS, D.L.; RUFATO, A. de R.; RUFATO, L. Avaliação física, química e fitoquímica de frutos de Physalis, ao longo do período de colheita. Revista Brasileira de Fruticultura, v.34, p.1004-1012, 2012. DOI: https://doi.org/10.1590/S0100-29452012000400006.

LÓPEZ ENRÍQUEZ, D.F.L.; RUANO, L.Y.C.; ANDRADE, J.C.; MORA, O.O. Evaluación de un recubrimiento comestible a base de proteínas de lactosuero y cera de abeja sobre la calidad fisicoquímica de uchuva (Physalis peruviana L.). Acta Agronómica, v.65, p.326333, 2016. DOI: https://doi.org/10.15446/acag.v65n4.50191.

MARTINS, E.; APARECIDO, L.E. de O.; SANTOS, L.P.S.; MENDONÇA, J.M.A. de; SOUZA, P.S. de. Influência das condições climáticas na produtividade e qualidade do cafeeiro 
produzido na região do sul de Minas Gerais. Coffee Science, v.10, p.499-506, 2015.

PALOMINO, C.E.M.; MUNOZ-FLOREZ, J.E.; VASQUEZAMARILES, H.D.; BARRERA-MARIN, N. Caracterización morfológica de 29 introducciones de Physalis peruviana L. de la colección de trabajo de la Universidad Nacional de Colombia Sede Palmira. Acta Agronómica, v.60, p.68-75, 2011.

PENA, D.S.; EVANGELISTA, A.W.P.; ALVES JÚNIOR, J.; CASAROLI, D. Agroclimatic zoning for jatropha crop (Jatropha curcas L.) in the State of Goiás. Acta Scientiarum. Agronomy, v.38, p.329-335, 2016. DOI: https://doi.org/10.4025/actasciagron.v38i3.28224.

RUFATO, L.; RUFATO, A. de R.; SCHLEMPER, C.; LIMA, C. S. M.; KRETZSCMAR, A. A. Aspectos técnicos da cultura da physalis. Pelotas: Ed. da UFPEL, 2008. 100p.

SALAZAR, M.R.; JONES, J.W.; CHAVES, B.; COOMAN, A. A model for the potential production and dry matter distribution of Cape gooseberry (Physalis peruviana L.). Scientia Horticulturae, v.115, p.142-148, 2008a. DOI: https://doi.org/10.1016/j.scienta.2007.08.015.
SALAZAR, M.R.; JONES, J.W.; CHAVES, B.; COOMAN, A.; FISCHER, G. Base temperature and simulation model for nodes appearance in cape gooseberry (Physalis peruviana L.). Revista Brasileira de Fruticultura, v.30, p.862-867, 2008b. DOI: https://doi.org/10.1590/S0100-29452008000400004.

SINCLAIR, T.R.; LUDLOW, M.M. Influence of soil water supply on the plant water balance of four tropical grain legumes. Functional Plant Biology, v.13, p.319-340, 1986. DOI: https://doi.org/10.1071/PP9860329.

TAIZ, L.; ZEIGER, E. Fisiologia e desenvolvimento vegetal. 6.ed. Porto Alegre: Artmed, 2017. 722p.

THORNTHWAITE, C.W. An approach toward a rational classification of climate. Geographical Review, v.38, p.55-94, 1948.

THORNTHWAITE, C.W.; MATHER, J.R. The water balance. Centerton: Drexel Institute of Technology, Laboratory of Climatology, 1955. 104p. (Publications in climatology, v.8, n.1)

WOLLMANN, C.A.; GALVANI, E. Zoneamento agroclimático: linhas de pesquisa e caracterização teórica-conceitual. Revista Sociedade \& natureza, v.25, p.179-190, 2013. DOI: https://doi.org/10.1590/S1982-45132013000100014. 